\title{
The spatial scale of ozone depletion events derived from an autonomous surface ozone network in coastal Antarctica
}

\author{
A. E. Jones ${ }^{1}$, E. W. Wolff ${ }^{1}$, N. Brough ${ }^{1}$, S. J.-B. Bauguitte ${ }^{1, *}$, R. Weller ${ }^{2}$, M. Yela ${ }^{3}$, M. Navarro-Comas ${ }^{3}$, H. A. Ochoa ${ }^{4}$, \\ and N. Theys ${ }^{5}$ \\ ${ }^{1}$ British Antarctic Survey, Natural Environment Research Council, Cambridge, UK \\ ${ }^{2}$ Alfred Wegener Institute, Bremerhaven, Germany \\ ${ }^{3}$ INTA, Área de Investigación e Instrumentación Atmosférica,Torrejón de Ardoz, Spain \\ ${ }^{4}$ Dirección Nacional del Antártico/Instituto Antártico Argentino (DNA/IAA), Buenos Aires, Argentina \\ ${ }^{5}$ Belgian Institute of Spatial Aeronomy (IASB-BIRA), Bruxelles, Belgium \\ * now at: Facility for Airborne Atmospheric Measurements, Natural Environment Research Council, Cranfield, UK
}

Correspondence to: A. E. Jones (aejo@bas.ac.uk)

Received: 3 September 2012 - Published in Atmos. Chem. Phys. Discuss.: 19 October 2012

Revised: 22 January 2013 - Accepted: 23 January 2013 - Published: 6 February 2013

\begin{abstract}
To probe the spatial extent of tropospheric ozone depletion events during Antarctic spring, a network of $10 \mathrm{au}-$ tonomous ozone monitors was established around the Dronning Maud Land sector of Antarctica for a full calendar year. Together with manned stations in the area, the network covered a $\sim 1200 \mathrm{~km}$ stretch of coast, as well as a transect $\sim 300 \mathrm{~km}$ inland and to $\sim 2000 \mathrm{~m}$ above sea level (a.s.l.). Here we present results from the spring period (August to October 2008). While some ozone depletion events were evident at only a single site, implying localised ozone destruction, others were evident across the network. The fact that, on occasions, ozone depletion events were observed at all coastal sites simultaneously, suggests the depleted air mass had a scale of at least $1200 \mathrm{~km}$. As the ozone-poor air was advected from the Weddell Sea sea ice zone, the data imply that large areas over the Weddell Sea sea ice zone are significantly depleted in ozone on occasions during Antarctic spring.
\end{abstract}

\section{Introduction}

Ozone is a critical component of tropospheric chemistry. It is a highly reactive oxidant, and the primary source of hydroxyl radicals to the troposphere. Through its capacity to absorb infra-red radiation, it influences the radiative balance of the atmosphere, a role that becomes progressively more important towards altitudes of the tropopause (Lacis et al., 1990).

In polar regions, surface ozone is observed from a number of manned stations around the coastal perimeters as well as at a few inland stations. At all coastal sites, to a greater or lesser extent, the otherwise smoothly-varying seasonal cycle displays sporadic departures from background values during the spring months (Helmig et al., 2007). Referred to widely as tropospheric ozone depletion events (ODEs), these departures are characterised by a reduction in ozone from background concentrations, sometimes to near instrumental detection limits, with concentrations remaining suppressed for on the order of hours to a few days. The primary driver of ozone loss is destruction by bromine radicals via the reaction $\mathrm{Br}^{*}+\mathrm{O}_{3} \rightarrow \mathrm{BrO}+\mathrm{O}_{2}$. Bromine monoxide $(\mathrm{BrO})$ is thus a marker for ozone-depletion chemistry. While the source of bromine is known to be associated with the sea ice zone, emanating from the salinity available there, the precise source(s) for release are still under debate (e.g. McConnell et al., 1992; Vogt et al., 1996; Frieß et al., 2004; Rankin et al., 2002; Kaleschke et al., 2004; Simpson et al., 2007a; Yang et al., 2008; Jones et al., 2009; Yang et al., 2010).

The spatial extent of ODEs, which ultimately determines their wider influence, is difficult to pin down. Aircraft observations made during the Arctic Tropospheric Ozone Production about the Spring Equinox (TOPSE) programme revealed one depleted air mass that stretched $\sim 900 \mathrm{~km}$ along the flight 
track and another that was at least $600 \mathrm{~km}$ long (Ridley et al., 2003, 2007). These air masses were observed away from the sea ice zone, and were interpreted as having been transported from over the Arctic Ocean. The density and distribution of research stations measuring surface ozone, however, either in the Arctic or Antarctic, are insufficient to determine the size of depleted air masses even in the coastal margins. Single-point observations from coastal stations can only address the time period over which air masses are depleted in ozone. They raise the question whether ODEs are relatively short-lived events that occur episodically, or whether they are more sustained within the sea ice zone and are merely observed episodically when meteorological conditions bring ozone depleted air masses to the observation point. Measurements from ice camps (Hopper et al., 1994, 1998), and from ships within the sea ice zone (Bottenheim et al., 2009; Jacobi et al., 2010) support the latter view. In particular, measurements made from the schooner "TARA" that drifted with the frozen Arctic Ocean, revealed sustained surface ozone depletion during spring that lasted on the order of weeks (Bottenheim et al., 2009). These observations suggest that vast areas over the Arctic Ocean are effectively void of ozone during the spring months.

The findings of Bottenheim et al. (2009) are entirely consistent with space-borne observations of $\mathrm{BrO}$ during Arctic springtime, which regularly show significant enhancements in the vertical column density that extend over considerable areas (Richter et al., 1998; Simpson et al., 2007b). While a contribution to these "hotspots" of enhanced vertical column is likely to arise in the stratosphere, a significant component has been shown to exist in the troposphere (Wagner and Platt, 1998; Theys et al., 2009, 2011; Salawitch et al., 2010).

Such BrO enhancements are also evident over the Antarctic sea ice zone during the spring, suggesting that a similarly extensive depletion of tropospheric ozone most likely also occurs in the south. However, there have been no measurements from manned aircraft to probe the extent of ozone depletion over the springtime Antarctic sea ice zone due to the harsh environmental conditions during the ODE-season. While Unmanned Autonomous Vehicles (UAVs) fitted with ozone sensors would be an option to probe air masses over the sea ice zone, such experiments remain to be done. Similarly, no equivalent to the TARA study has yet been conducted in Antarctica, and the recently-developed O-buoy system (Knepp et al., 2010) has thus far only been deployed in the Arctic.

As an alternative approach to assessing the spatial extent of Antarctic tropospheric ozone depletion events, 10 autonomous ozone monitors were installed in 2008 around Dronning Maud Land (DML), Antarctica, that, together with data from nearby manned stations (Halley, Belgrano II (hereafter referred to as Belgrano) and Neumayer), would provide the potential to map the movement and size of ozonedepleted air masses over the region. The network extended along $\sim 1200 \mathrm{~km}$ of the coastal perimeter, with a transect running $\sim 300 \mathrm{~km}$ up towards the polar plateau (to $\sim 2000$ $\mathrm{m}$ a.s.l.), and one site at sea level on an ice shelf but roughly $200 \mathrm{~km}$ inland. Data from the network thus allow us to address three questions: (i) What is the spatial extent of ODEs along the Weddell Sea coast? (ii) How far inland and to what altitudes do ODEs extend at the edge of the polar plateau? (iii) How far inland do ODEs extend across a flat ice shelf?

\section{Experimental}

A full description of the experimental approach (both site descriptions and instrumentation) for the autonomous systems is given in an associated technical paper (Bauguitte et al., 2011), so only a brief summary is presented here.

\subsection{Location and description of sites}

Figure 1a shows a map of the experimental region, indicating the position of the autonomous sensors and the manned stations (Halley, Belgrano and Neumayer) that contributed data to the network. From Neumayer at the northernmost reaches to Site $\mathrm{I}$ in the south west there is a distance of roughly $1200 \mathrm{~km}$ as the crow flies. Site E is roughly $300 \mathrm{~km}$ from Site B on the coast and at an altitude of $2000 \mathrm{~m}$, with Sites C and $\mathrm{D}$ providing information on ozone at intermediate locations. The ozone monitor at Site F, at the head of the transect (2630 m a.s.1.) unfortunately did not return useful data during the spring. Sites I and J are both on the Filchner Ice Shelf, at roughly the same altitude, but with Site $J 200 \mathrm{~km}$ further inland. Table 1 provides an overview of site details.

Figure 1b shows an AMSR-E (Spreen et al., 2008) map of sea ice for 7 October 2008, highlighting the extent and concentration of sea ice at this time of the year.

\subsection{Technical/instrumentation}

The autonomous sensor systems are based around a 2B Technologies Inc. Model 202 ozone monitor, which is a single channel UV photometric instrument that measures ozone from its absorption band at $254 \mathrm{~nm}$ (Wilson and Birks, 2006). The instruments have a manufacturer specification of accuracy and precision for $1 \mathrm{~min}$ data of 1.5 parts per billion by volume (ppbv) or $2 \%$ of reading once corrected for longterm drift, and a limit of detection of 3 ppbv. Power was provided for the monitors from AGM lead acid gel cell batteries which were charged from a vertical axis Forgen 500 wind turbine and a $40 \mathrm{~W}$ Kyocera solar panel. Zero ozone measurements were taken at the start and the end of the deployment period, as described in Bauguitte et al. (2011). The instrument duty cycle over the year was designed to give continuous sampling during spring, when fast changes in ozone concentrations were anticipated. While this was achieved for much of the spring at many sites, interruptions nonetheless occurred when charging was insufficient to maintain battery supply voltages above their threshold limit, and the systems 


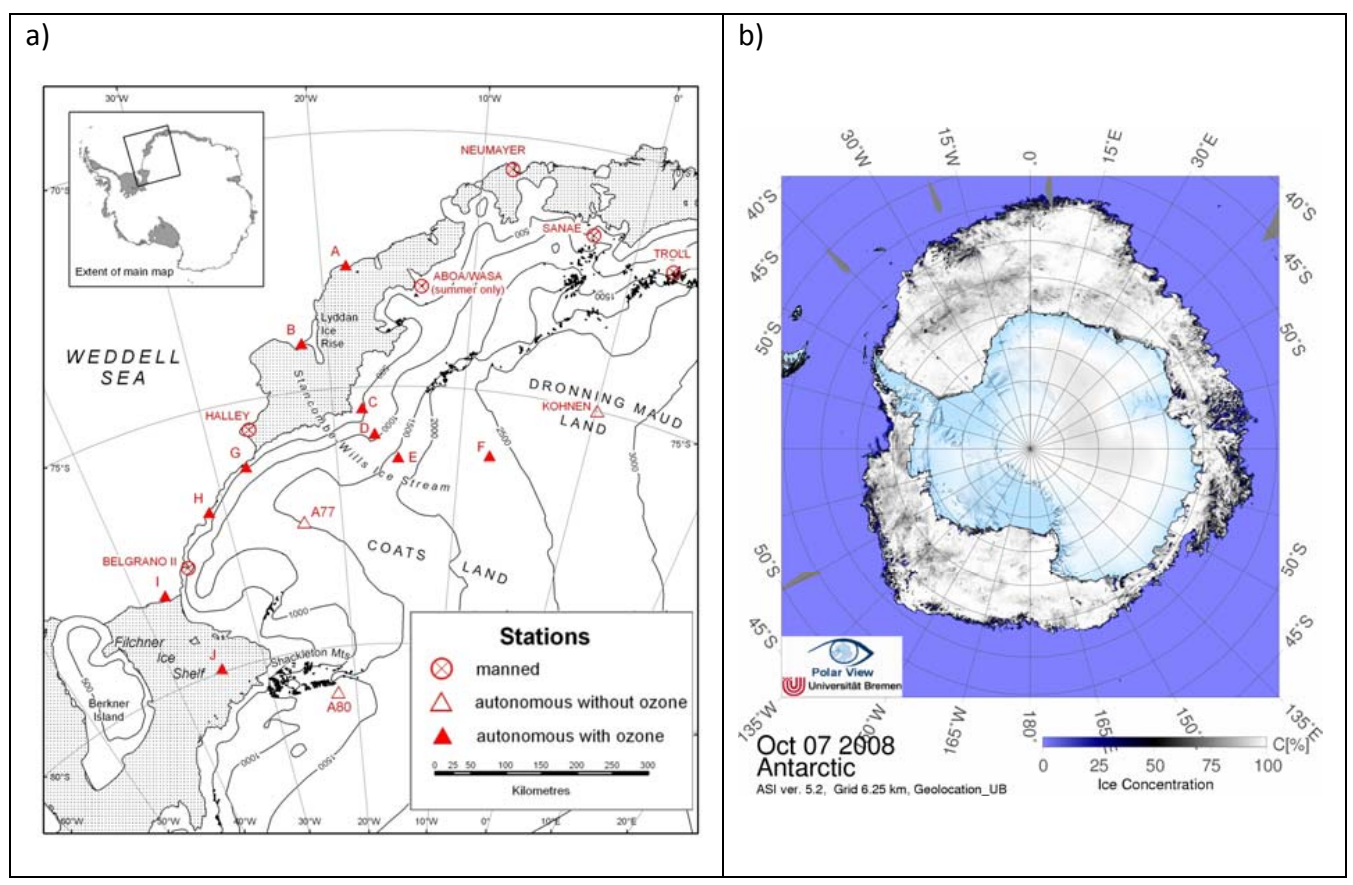

Fig. 1. (a) Map of study area showing both the autonomous sites (Sites A to J) and the manned stations (Neumayer, Halley and Belgrano II) contributing to the network; (b) AMSR-E map of sea ice extent and concentration for 7 October 2008.

temporarily switched off to allow the batteries to recharge. Following such down times, the instruments required a short time for the signal to stabilise again. Such recoveries were aided by instrument modifications that had been made to deal with the low anticipated ambient temperatures (described in Bauguitte et al., 2011).

Data were stored as $1 \mathrm{~min}$ averages of $10 \mathrm{~s}$ data, and in response to the required stabilisation, a first-pass filter that removed 3 data points was applied after every instrument down time. For the majority of the springtime data this was sufficient, but when stabilisation took longer, additional points were removed (up to 10 on occasions).

Both Halley and Belgrano station operated a Thermo Electron Model 49C dual-cell surface ozone analyser for which manufacturer-stated precision and limit of detection are both 1 ppbv. At Neumayer, surface ozone was measured using an Environnement s.a O3 41M, for which the accuracy is $\pm 0.5 \mathrm{ppbv}$ and the detection limit is better than $1 \mathrm{ppbv}$ based on $1 \mathrm{~min}$ averages. At each station, regular zeros and span checks are performed. Data presented from the manned stations are filtered to remove any influence of local pollution.

All data presented here, for both the autonomous sites and manned stations, are 10 min averages.
Table 1. Details of all ozone monitoring sites discussed in this paper.

\begin{tabular}{llrl}
\hline Site & Location & $\begin{array}{r}\text { Altitude } \\
\text { (m a.s.l.) }\end{array}$ & Role in network \\
\hline Neumayer & $70^{\circ} 40^{\prime} \mathrm{S} 08^{\circ} 15^{\prime} \mathrm{W}$ & $\sim 30$ & coastal \\
$\mathrm{A}$ & $72^{\circ} 36^{\prime} \mathrm{S} 18^{\circ} 23^{\prime} \mathrm{W}$ & $\sim 30$ & coastal \\
$\mathrm{B}$ & $74^{\circ} 04^{\prime} \mathrm{S} 21^{\circ} 49^{\prime} \mathrm{W}$ & $\sim 30$ & coastal/plateau transect \\
Halley & $75^{\circ} 35^{\prime} \mathrm{S} 26^{\circ} 34^{\prime} \mathrm{W}$ & $\sim 30$ & coastal \\
$\mathrm{C}$ & $75^{\circ} 24^{\prime} \mathrm{S} 17^{\circ} 44^{\prime} \mathrm{W}$ & $\sim 500$ & plateau transect \\
$\mathrm{D}$ & $75^{\circ} 55^{\prime} \mathrm{S} 16^{\circ} 50^{\prime} \mathrm{W}$ & 1030 & plateau transect \\
$\mathrm{E}$ & $76^{\circ} 23^{\prime} \mathrm{S} 14^{\circ} 58^{\prime} \mathrm{W}$ & $\sim 2000$ & plateau transect \\
$\mathrm{F}$ & $76^{\circ} 15^{\prime} \mathrm{S} 07^{\circ} 30^{\prime} \mathrm{W}$ & 2630 & plateau transect \\
$\mathrm{G}$ & $76^{\circ} 16^{\prime} \mathrm{S} 27^{\circ} 27^{\prime} \mathrm{W}$ & $\sim 30$ & coastal \\
$\mathrm{H}$ & $76^{\circ} 58^{\prime} \mathrm{S} 31^{\circ} 22^{\prime} \mathrm{W}$ & $\sim 30$ & coastal \\
Belgrano II & $77^{\circ} 52^{\prime} \mathrm{S} 34^{\circ} 37^{\prime} \mathrm{W}$ & $\sim 256$ & coastal \\
I & $78^{\circ} 13^{\prime} \mathrm{S} 37^{\circ} 32^{\prime} \mathrm{W}$ & $\sim 30$ & coastal \\
$\mathrm{J}$ & $79^{\circ} 56^{\prime} \mathrm{S} 34^{\circ} 45^{\prime} \mathrm{W}$ & 125 & inland ice shelf \\
\hline
\end{tabular}

\section{Results and discussion}

\subsection{ODEs along the Weddell Sea/Dronning Maud Land coast}

Figure 2 shows a time-series of surface ozone measurements from the autonomous sites and manned stations that operated along the coast of the Weddell Sea, during the austral spring period 1 August to 31 October 2008. While the data quality varies between locations, features in the data set are clearly discernible. 


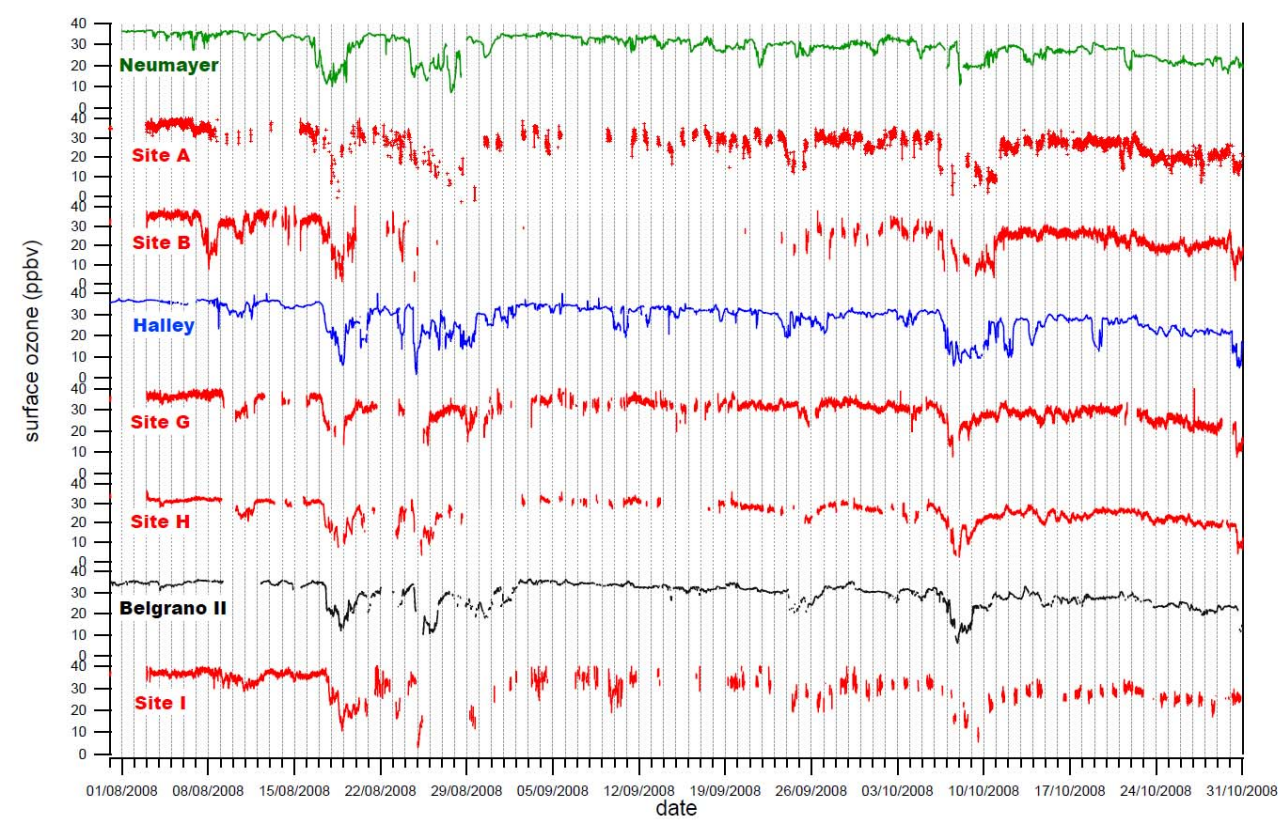

Fig. 2. Time-series of surface ozone measurements from the autonomous sites and manned stations that operated along the coast of the Weddell Sea, during the austral spring period 1 August to 31 October 2008. Tick marks denote midnight at the start of the day.

For example, superimposed on periods with relatively stable ozone concentrations are depletion events that are visible at single stations only. A clear example can be seen on 19 October, where ozone mixing ratios at Halley drop from their background of $\sim 30 \mathrm{ppbv}$ to a minimum of $13 \mathrm{ppbv}$, the depletion lasts for $21 \mathrm{~h}$, but no equivalent signal is seen at any of the other observation sites. Such a location-specific signature, that is not visible even $80 \mathrm{~km}$ away at Site G, suggests that the depletion is driven by local processes.

In contrast, remarkable similarities in features at different observation sites are also evident in the data series. For example, significant ozone depletion is observed at all locations during the period 16 to 22 August (shown in greater detail in Fig. 3a). This is a remarkable period where even the structure in the depletion - with an initial drop in concentrations, a period with stable but lower ozone, followed by a drop to the minimum - is similar between certain sites (compare, for example, Site B, Halley, Belgrano, and Site I). A further period of depletion is evident from 24 to 30 August at all sites where data quality is good, and, where data coverage is more limited, evidence for depletion is still visible. Later in the series, from 6 to 11 October, further large-scale depletion is evident at all sites, to a greater or lesser extent (Fig. 3b).

These large-scale depletion events, visible across the coastal network sites, are clearly regional phenomena, and driven by large-scale processes.

Some insight into the regional situation can be gained from observations of the $\mathrm{BrO}$ column made by the satellite-borne GOME-2 instrument (Munro et al., 2006). Maps of tropospheric $\mathrm{BrO}$ vertical column density (VCD) were derived us- ing the analysis of Theys et al. (2011). This is performed by subtracting from the measured total $\mathrm{BrO}$ column a stratospheric column derived from a climatology which makes use of dynamical and chemical indicators and is based on a chemical transport model (Theys et al., 2009). Note that in order to keep a maximum number of pixels, no filtering for clouds was applied and stratospheric air mass factors were used as scaling factors. Figure 4 shows tropospheric $\mathrm{BrO}$ VCD from 16 to 21 August, the first period of significant ozone depletion across the network. Data coverage is limited because measurements are being made close to the terminator and data analysis is restricted to solar zenith angles (SZA) below $90^{\circ}$. However, where data exist, they show significant $\mathrm{BrO}$ activation in the northernmost (sunlit) region of the Weddell Sea. The structure of the BrO VCD observations, with high VCD evident at the edge of the satellite swaths, suggest that areas between the satellite swathes (as well as further poleward) where no data are reported, also have some enhanced $\mathrm{BrO}$.

To examine the broader meteorological conditions, we use ECMWF-operational analyses of mean sea level pressure (mslp) and 10-m wind vectors which, for 2008, are available at a horizontal resolution of $25 \mathrm{~km}$. Such analyses allow the origin of the air masses arriving at the coastal network sites (continental or sea ice zone) to be estimated and also show the synoptic scale weather systems that are driving the air mass transport. The ODE of 16 to 22 August occurred during a period of rapidly changing meteorological conditions.

It is known that, in the absence of synoptic scale forcing, the Weddell Sea coastal region is predominantly influenced 

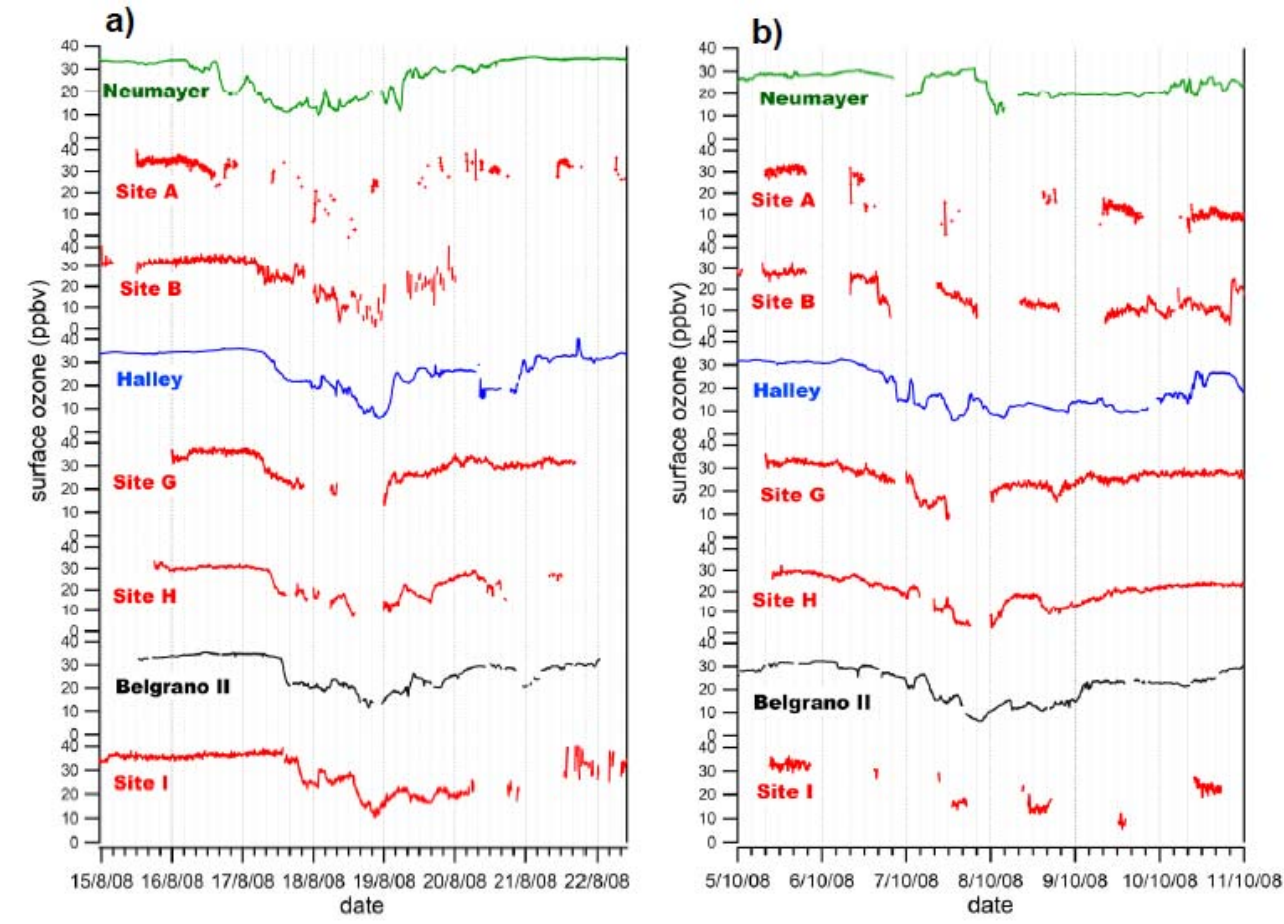

Fig. 3. Major ozone depletion events that were evident at all coastal stations, (a) from 16 to 22 August, (b) from 6 to 11 October. Tick marks denote midnight at the start of the day.

\section{GOME-2 BrO tropospheric VCD}
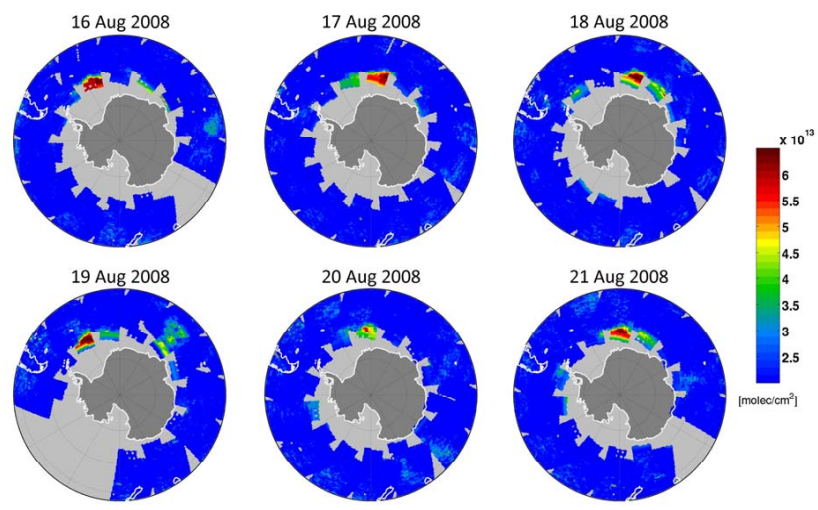

Fig. 4. Tropospheric vertical column density $\mathrm{BrO}$ derived from the GOME-2 instrument during the August ozone depletion event. Areas of light grey have no data.

by katabatic flow from the continental interior during the winter and spring months (King, 1993). Prior to the onset of the August ODE, a low pressure system was situated over the northern Weddell Sea, but sufficiently far from the continent to have no influence on air mass transport at the coast, which remained under the influence of katabatic outflow. Over the next twelve hours, however, the low pressure system tracked to the north and east, eventually reaching the coast around
Neumayer (see Fig. 5a) and directing sea ice-zone air to the station. Observations at Neumayer and Site A showed partial ozone depletion at this time, while all observing sites further south retained background ozone amounts. By midnight at the start of 17 August, the low had moved further north and dissipated (Fig. 5b). Some recovery in ozone was evident at Neumayer and Site A around this time, with the other, more southerly, network sites remaining unaffected. Also evident in Fig. 5b is a small low pressure system in the lee of the Antarctic Peninsula. Over the following hours, this low tracked progressively south-eastwards towards the coast of Dronning Maud Land, growing in size and deepening as it did so. Its transport, and increasing influence on the Weddell Sea coastal region, corresponds to reductions in ozone measured across the network as sea ice zone-air was advected in to the region. The ODE was first apparent at Site B, Halley and Site G, around 06:00 UTC on 17 August, and progressively later at the more southerly sites, with an eventual onset at Site I around noon on 17 August. Its onset signature at Neumayer is complicated by the residual influence of the previous low from which the station had not fully recovered. By midnight at the start of 18 August, the low was directly over the Dronning Maud Land coast (Fig. 5c) such that all observing sites within the network were under its influence. The ECMWF-operational 10-m wind vectors for this time (Fig. 5d) show rapid air flow down the Weddell Sea coast, with wind speeds between 16 and $20 \mathrm{~ms}^{-1}$ between Sites A 
a)

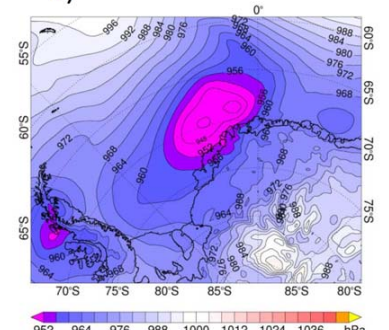

c)

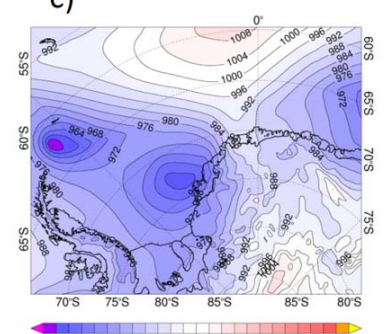

e)

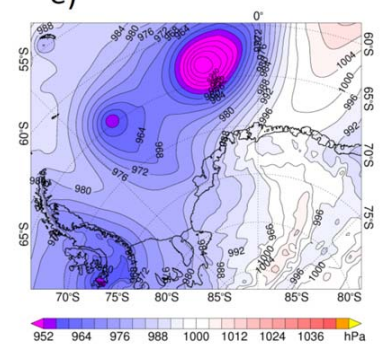

b)

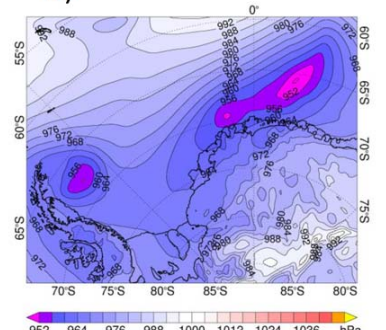

d)

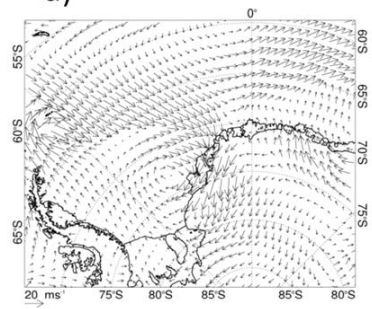

f)

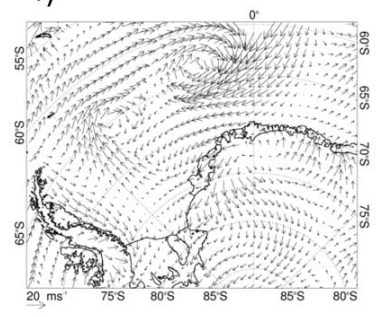

Fig. 5. ERA-Operational meteorological maps around the Weddell Sea region at various times during the major August ozone depletion event. (a) Mean sea level pressure (mslp) at noon on 1 August; (b) mslp at midnight at start of 17 August; (c) mslp at midnight at start of 18 August; (d) 10-m wind vectors at midnight at start of 18 August; (e) mslp at midnight at start of 19 August; (f) 10-m wind vectors at midnight at start of 19 August.

and G. Over the next twelve hours, the low pressure system dissipated. Figure 5e shows the mslp at midnight at the start of 19 August, the time of maximum ozone depletion across the network. Although wind speeds across the region had dropped, air was still channelling in a south-westerly direction down the coast (Fig. 5f), advecting sea ice zone-air to all the coastal network sites. By noon on 21 August only the southernmost observation sites, Site I, Belgrano and Site H, were weakly influenced by a Weddell Sea low, while the rest of the network was once again influenced by katabatic flow. Accordingly, residual ozone depletion was evident at Site I, Belgrano and Site $\mathrm{H}$, but at all other sites, ozone mixing ratios were close to background once again.

Around the time of the major October ozone depletion event, significant enhancements in the tropospheric $\mathrm{BrO}$ VCD are clearly visible over the Weddell Sea sea ice zone and around the coast of Dronning Maud Land (Fig. 6). Given that $\mathrm{BrO}$ is evident over the northernmost $\mathrm{O}_{3}$ network sites

\section{GOME-2 BrO tropospheric VCD}

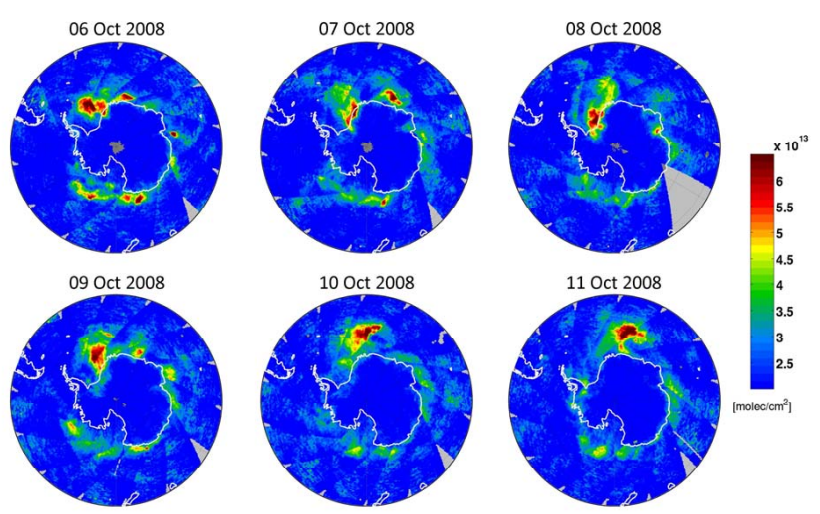

Fig. 6. Tropospheric vertical column density $\mathrm{BrO}$ derived from the GOME-2 instrument during the October ozone depletion event.

on 6 October, and that the satellite measures at 09:30 local time it is somewhat surprising that no $\mathrm{O}_{3}$ depletion is observed in the first part of the day. However, no information is contained in the satellite data as to where in the vertical column the $\mathrm{BrO}$ enhancement occurs, and previous work has shown that enhanced $\mathrm{BrO}$ is not restricted to the lowermost mixed layers (e.g. Choi et al., 2012; Roscoe et al., 2012). One can therefore postulate that the 6 October tropospheric $\mathrm{BrO}$ enhancement is not influencing the lowermost air masses, but resides aloft in the tropospheric column.

The ECMWF-operational analyses in Fig. 7 show that the synoptic situation during this period was quite different in character to that of the August ODE discussed above. Rather than the series of rapidly moving low pressure systems, the October ODE was associated with a quasi-stationary low situated off-shore of Halley. While present at the start of 6 October, the low was situated sufficiently far off-shore to have no influence on the prevailing katabatic outflow. By midnight at the start of 7 October, however, the low had moved further inland (Fig. 7a) such that sea ice zone air was advected to the Weddell Sea coast. The 10-m wind vectors (Fig. 7b) show sea ice-zone air being directed particularly to the northern and central network sites, with wind speeds of the order 8 to $12 \mathrm{~ms}^{-1}$. Ozone depletion at this time was particularly evident at Site B and Halley, with reductions in ozone of $\sim 17$ and $\sim 18$ ppbv respectively, with more moderate depletion evident at Neumayer (roughly $12 \mathrm{ppbv}$ ). Site I, in the south, however, with little influence from sea ice zone air, showed little ozone depletion at this time. By noon on 8 October, a small secondary low had formed over the northern Weddell Sea (Fig. 7c). The effect on air flow is evident in the 10-m wind vectors (Fig. 7d), which show wind speeds of between 8 and $12 \mathrm{~ms}^{-1}$ around Neumayer, with air flow to the east, and much lower wind speeds (mostly $<4 \mathrm{~ms}^{-1}$ ), and air flow to the south east (although still with a sea ice zone origin) around the other network sites. The lows dissipated over the 
a)

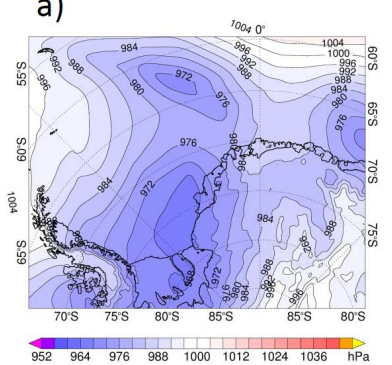

c)

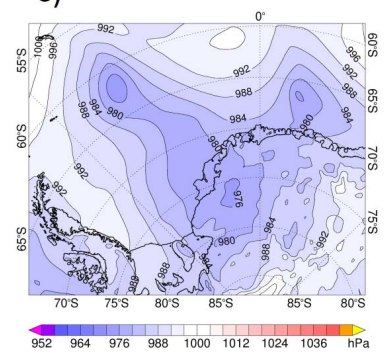

b)

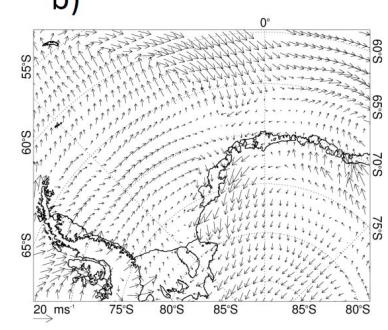

d)

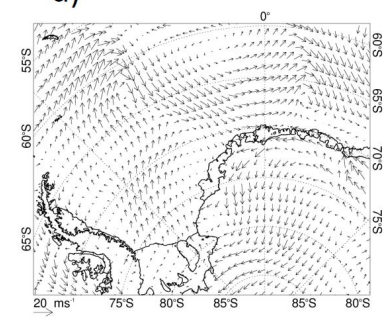

Fig. 7. ERA-Operational meteorological maps around the Weddell Sea region at various times during the major October ozone depletion event. (a) Mean sea level pressure (mslp) at midnight at the start of 7 October; (b) 10-m wind vectors at midnight at the start of 7 October; (c) mean sea level pressure (mslp) at noon on 8 October; (b) 10-m wind vectors at noon on 8 October.

subsequent $24 \mathrm{~h}$. By noon on 10 October, while most of the network sites were once again under continental air mass influence, a slow moving low was approaching the Halley/Site $\mathrm{B}$ region. This caused some additional sea ice zone air flow to these sites, as reflected by the variation in the surface ozone signals.

Taken together, these results imply that, given wide spread bromine activation and ozone depletion over the sea ice zone, whether or not ozone-depleted air masses were observed at coastal stations was an extremely subtle function of transport, and the balance between air flow dominated by sea ice zone or continental influence.

\subsection{The spatial extent of ODEs along the Weddell Sea/Dronning Maud Land coast}

To explore the spatial scale of such regional ozone depletion events, we focus on the event of 16 to 22 August, because data quality is generally good at all observation sites. We calculated, at 12 hourly intervals, the surface ozone anomaly at each site relative to the sites' $12 \mathrm{~h}$ average $\mathrm{O}_{3}$ amount before depletion began. The data were plotted as a function of distance from Site I in order to generate transects showing ozone depletion along the coast. The results for the time slices are shown in Fig. 8, and the evolution of the ozone depletion "event" along the coast now becomes apparent. Ozone loss is first apparent at Site A at noon on 16 August. By midnight on 17 August, no data are available from Site A, but deple-

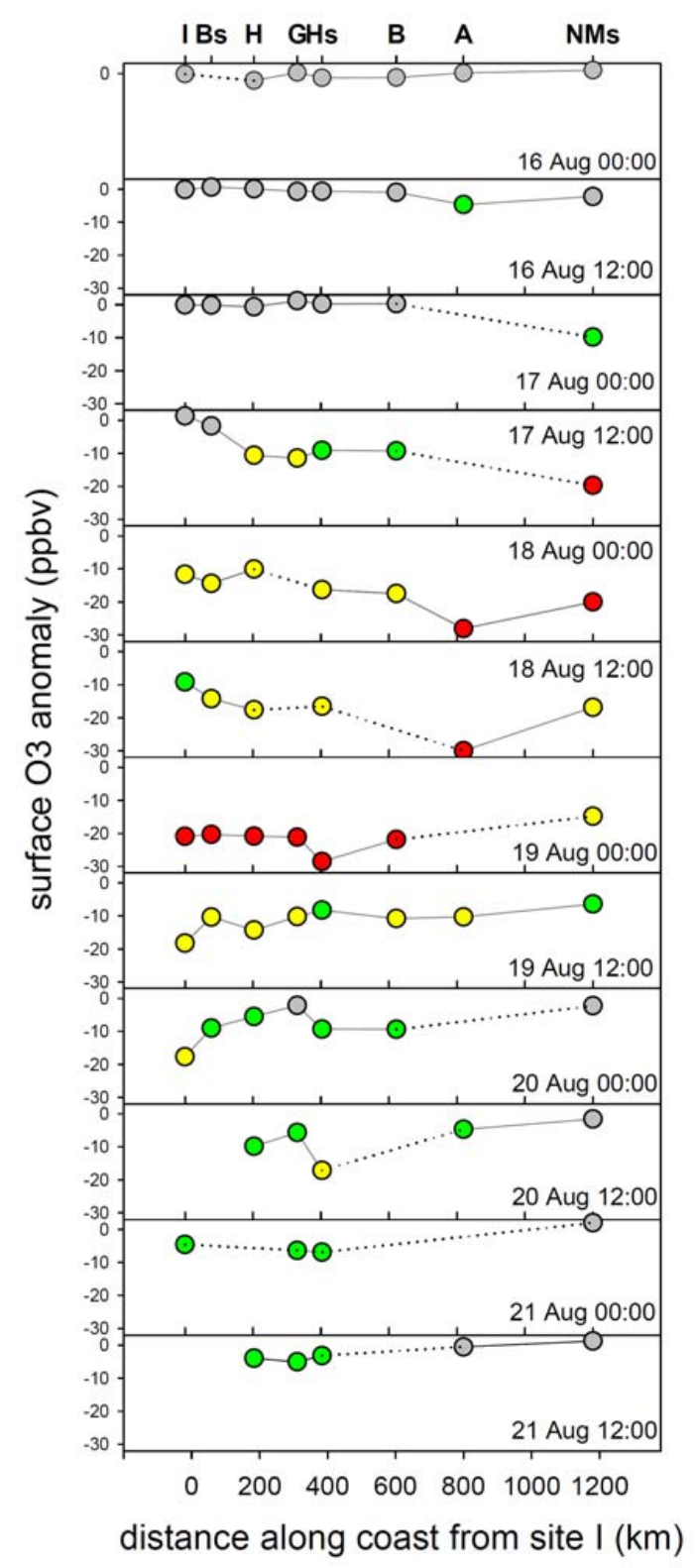

Fig. 8. Surface ozone anomaly (i.e. difference in mixing ratio) at each site relative to the $12 \mathrm{~h}$ average at that site before depletion began, plotted at $12 \mathrm{~h}$ intervals, as a function of distance around the coast from Site I. Colour coding emphasises amount of ozone loss - grey: 0 to 2.5 ppbv; green: 2.5 to 10 ppbv; yellow: 10 to $20 \mathrm{ppbv;}$ red: more than $20 \mathrm{ppbv}$. Positions of the autonomous sites are indicated on the top axis; Bs, Hs, and NMs are Belgrano II station, Halley station and Neumayer station respectively. Dotted lines are used when data points are missing.

tion of just over $10 \mathrm{ppbv}$ is evident at Neumayer station. By noon on 17 August, depletion at Neumayer is severe (more than 20 ppbv $\mathrm{O}_{3}$ loss $)$, with moderate depletion ( $\left.\sim 10 \mathrm{ppbv}\right)$ evident at Sites H, G, Halley and B. Twelve hours later, at midnight on 18 August, depletion from Site I to Site B is 
of the order 10.5 to $20 \mathrm{ppbv}$, and greater than $20 \mathrm{ppbv}$ at the northernmost Site A and Neumayer. By midnight on $19 \mathrm{Au}-$ gust, the largest surface ozone anomaly is evident, with surface ozone depleted by over $20 \mathrm{ppbv}$ from Site I to Site B, and by $\sim 13 \mathrm{ppbv}$ at Neumayer. This time slice marks the maximum in ozone depletion measured along the DML coast, and demonstrates that the ozone-depleted air mass on this occasion extended for over $1200 \mathrm{~km}$ along the coast. Indeed, as depletion at Site I, at the southernmost edge of the measurement transect, was of the order $20 \mathrm{ppbv}$, the results suggest that Site I was still well within the depleted air mass, and that the edge of the depletion was still some distance away.

Over the subsequent $2 \frac{1}{2}$ days, surface ozone mixing ratios along the coast returned to their background amounts, and became, once again, more uniform in space.

\subsection{The propagation of ozone depletion inland}

While the results above were able to demonstrate the size of a depleted air mass along the coast, the surface ozone network was also able to probe how far inland depleted air masses might regularly extend. Occasional surface ozone depletion has been observed at South Pole during the spring (Helmig et al., 2007) and one event was studied and shown to arise from coastal processes around the Bellingshausen Sea (Buys et al., 2013). However, such events are exceptions rather than the rule. At the South African station, Sanae, located some $160 \mathrm{~km}$ from the ice shelf edge, but at an altitude of $856 \mathrm{~m}$ a.s.l., depleted air masses are not routinely observed (Helmig et al., 2007). Here we explore whether inland propagation is limited by distance from the sea ice or by increasing altitude.

\subsubsection{Influence of increasing terrain altitude on ozone propagation inland}

Figure 9 shows a time series of surface ozone observations from 4 autonomous sites that form a transect between sea level and $\sim 2000 \mathrm{~m}$ on the edge of the Antarctic plateau. Originally the network was designed with a fifth site, Site $\mathrm{F}$, at $2630 \mathrm{~m}$ a.s.l., but the system failed to measure during the winter period as a result of the extreme conditions (Bauguitte et al., 2011) so no data are available to include in the transect results.

While considerable variability in surface ozone mixing ratios is evident in the record from the lowermost Site, B, this variability becomes more muted as site altitude increases. The major regional ozone depletion events that were visible at all coastal stations, and discussed above, can also be seen in Fig. 9. The August event is clearly evident in Site $\mathrm{C}$ as well as in the coastal Site B, and although the data quality is very poor, there is a hint of the depletion also evident at Site D. The major ODE from 6 to 11 October is much better represented in the transect data, with a step-wise reduction in ozone loss with altitude. We note that the BrO VCD

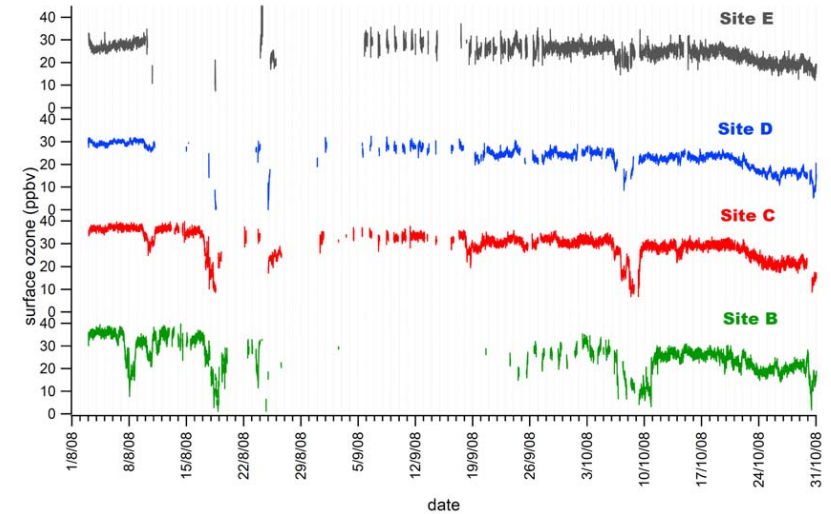

Fig. 9. Surface ozone (10-min averages) from 1 August 2008 to 31 October 2008 at 4 sites from a transect on the slope of the Antarctic plateau. Site E at $2000 \mathrm{~m}$ a.s.1., Site D at $1030 \mathrm{~m}$ a.s.1., Site C at 500 $\mathrm{m}$ a.s.1., Site $\mathrm{B}$ at the coast (30 $\mathrm{m}$ a.s.1.).

is also enhanced over the transect area during the October ODE (Fig. 6), although, again, we have no information on its vertical profile and thus the relation to the ozone-depleted air masses.

The surface ozone anomaly (i.e. difference in mixing ratio) at each site, relative to the $12 \mathrm{~h}$ average at that site before depletion began, is shown in Table 2 . While there is a noticeable difference in ozone reduction between Site B $(\sim 31 \mathrm{ppbv})$ and Site $\mathrm{C}(\sim 25 \mathrm{ppbv})$ during the August event, data quality did not allow an equivalent calculation for Sites D or E. For the October event, however, data coverage is better. On this occasion, $\sim 23 \mathrm{ppbv}$ ozone depletion was calculated at both Sites B and C, with 14 ppbv at Site D and 8 ppbv at Site E.

\subsubsection{Propagation of ozone depletion inland with no increase in terrain height}

In order to explore how far inland ozone depleted air masses can be transported when there is no increase in altitude, we examine data from Sites I and J, both located on the Filchner Ice Shelf but with Site $\mathbf{J} 200 \mathrm{~km}$ inland. As data quality at Site I is somewhat patchy, we also include data from the nearby Belgrano station.

Figure 10 shows time series of surface ozone during the major ozone depletion events of August and October, and Table 3 shows the surface ozone anomaly (calculated as described above) at each site during each event. For both ozone depletion events, the amount of ozone depletion is roughly equivalent at all sites. This suggests that ozone-depleted air masses remain intact over the distance of $200 \mathrm{~km}$ when there is no increase in altitude.

Given that the ice shelf has near zero salinity, the depletion events inland are clearly a result of transport rather than insitu chemistry. 

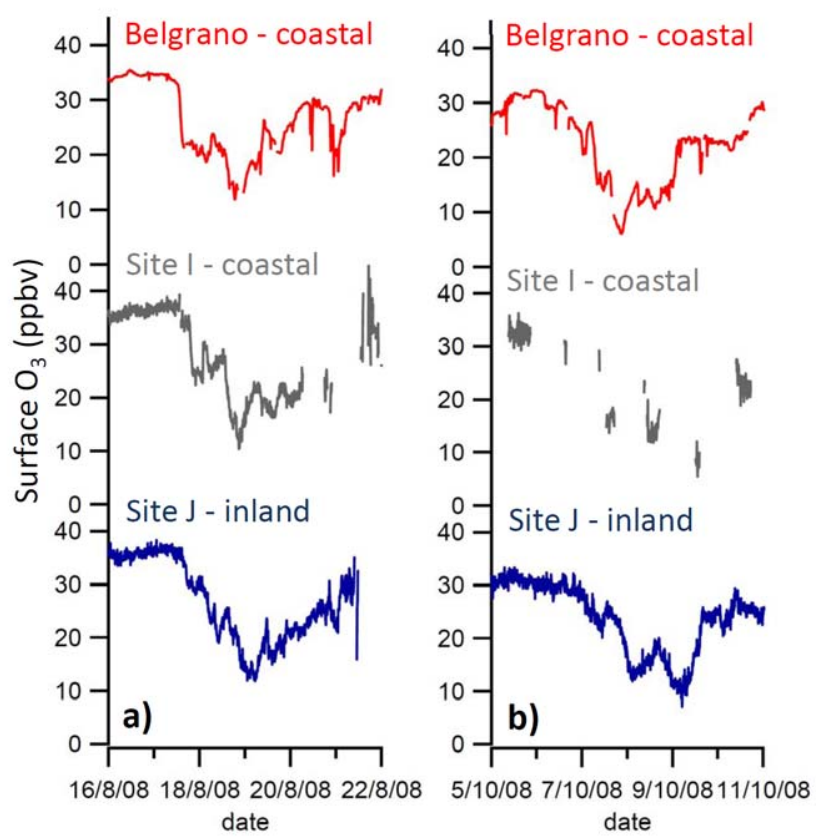

Fig. 10. Surface ozone time series (10 min averages) from three low altitude sites; I and J, both on the Filchner Ice Shelf but with J inland and I on the coast; and Belgrano II, on the coast near site I.

\subsection{The regional extent of ozone depletion}

To put results from the network into context, and to assess the wider implications of the observed ozone loss, we need to know how large the ozone depleted air masses were, both in terms of area, and also in terms of volume. As we only have measurements for the land mass, we restrict our analysis to the ice shelf/sheet area. We emphasise that this is likely to be a vast underestimate of the total area depleted in ozone, given that the ozone-depleted air masses observed by the network emanated from the sea ice zone, large areas of which are likely also depleted in ozone.

The results presented in this paper show that, at 00:00 on 19 August, all of the networks' coastal sites were significantly depleted in ozone (Fig. 2). Assuming an average background amount of $\sim 35 \mathrm{ppbv}$ ozone, then ozone loss was of the order $60 \%$. Results from the measurement transect (Fig. 9) show that, at the same time, ozone was depleted to at least $500 \mathrm{~m}$, and possibly as high as $1000 \mathrm{~m}$, by a similar amount. The area of land mass covered by the network, from the coast to an altitude of $500 \mathrm{~m}$, is $\sim 180000 \mathrm{~km}^{2}$. We can therefore assert that the ozone-depleted air mass on $19 \mathrm{Au}$ gust was at least this size, and most likely considerably more. The likely greater size is both because it extended further to the south west than Site I (which, given the amount of ozone depletion, was clearly not on the edge of the air mass) and also because we have taken no account here of the area of the sea ice zone affected. In terms of volume, merely over the land, at least $90000 \mathrm{~km}^{3}$ of boundary layer air were de-
Table 2. The surface ozone anomaly (i.e. difference in mixing ratio) during two major ozone depletion events observed at sites on a transect up onto the Antarctic plateau. The anomaly for each site was calculated relative to the $12 \mathrm{~h}$ average surface ozone observed at that site before depletion began. For the event of 18 August, data quality did not allow calculation of ozone loss for sites E or D.

\begin{tabular}{ccccc}
\hline & $\begin{array}{c}\text { Distance } \\
\text { inland }(\mathrm{km})\end{array}$ & $\begin{array}{c}\text { Altitude } \\
\text { (m a.s.1.) }\end{array}$ & $\begin{array}{c}\mathrm{O}_{3} \text { loss (ppbv) } \\
18 \text { August event }\end{array}$ & $\begin{array}{c}\mathrm{O}_{3} \text { loss (ppbv) } \\
\text { 8 October event }\end{array}$ \\
\hline $\mathrm{E}$ & 320 & 2000 & - & 8 \\
$\mathrm{D}$ & 250 & 1030 & - & 14 \\
$\mathrm{C}$ & 190 & 500 & 25 & 23 \\
$\mathrm{~B}$ & coastal & 30 & 31 & 23 \\
\hline
\end{tabular}

Table 3. As for Table 2, but now for a coastal and an inland site on the Filchner Ice Shelf (Site I and J respectively), as well as at a nearby coastal site (Belgrano II).

\begin{tabular}{lcccc}
\hline & $\begin{array}{c}\text { Distance } \\
\text { inland }(\mathrm{km})\end{array}$ & $\begin{array}{c}\text { Altitude } \\
(\mathrm{m} \text { a.s.l.) }\end{array}$ & $\begin{array}{c}\mathrm{O}_{3} \text { loss (ppbv) } \\
\text { 19 August event }\end{array}$ & $\begin{array}{c}\mathrm{O}_{3} \text { loss (ppbv) } \\
\text { 9 October event }\end{array}$ \\
\hline Belgrano II & coastal & 256 & 23 & 26 \\
$\mathrm{I}$ & coastal & 30 & 26 & $25^{*}$ \\
J & 200 & 125 & 24 & 22 \\
\hline
\end{tabular}

* For the event of 9 October, we note the reduced data quality at Site I, hence the calculated value of ozone loss is less robust than at the other sites.

pleted in ozone by $\sim 60 \%$. Depletion of a similar order of magnitude was also observed in October.

\section{Conclusions}

The results presented in this paper demonstrate, for the first time, the spatial extent of ozone depletion during Antarctic spring. They are entirely in line with results from the Northern Hemisphere TOPSE experiment, which measured a depleted air mass of the order $900 \mathrm{~km}$ along a flight track (Ridley et al., 2003). They are also consistent with the results from the "TARA" experiment, and the large areas of the Arctic Ocean that were effectively void of ozone (Bottenheim et al., 2009). The fact that ozone-poor air is advected roughly simultaneously to a $\sim 1200 \mathrm{~km}$ stretch of the DML coast implies the presence of a large pool of $\mathrm{O}_{3}$-depleted air over the Weddell Sea sea ice zone at that time.

The wider implications of ozone depletion events and their associated chemistry have been introduced in previous publications (e.g. Simpson et al., 2007b and references therein). Enhanced concentrations of bromine radicals, evident from satellite measurements of $\mathrm{BrO}$, and widespread destruction of tropospheric ozone, indicate a switch in the oxidation regime from one dominated by $\mathrm{OH}$ to one dominated by halogens. While this situation has been alluded to in the Arctic (e.g. Jacobi et al., 2010), it appears from the results presented here to also hold true for Antarctica. On a regional basis, a key impact from an increase in the $\mathrm{BrO}: \mathrm{OH}$ ratio is on DMS and the consequent influence on aerosol production. 
Certainly, results from year-round measurements of DMS and $\mathrm{BrO}$ at Halley station (Read et al., 2008) show a reduction in DMS during the spring, when ambient $\mathrm{BrO}$ is at its annual maximum, relative to the previous and subsequent weeks.

Furthermore, ozone itself is a greenhouse gas, such that a reduction in concentration will also have a direct influence on radiative forcing. Assuming complete removal of $40 \mathrm{ppbv}$ of ozone in a $300 \mathrm{~m}$ boundary layer, Jacobi et al. (2010) calculate a resultant radiative forcing of $-0.04 \mathrm{~W} \mathrm{~m}^{-2}$. Roscoe et al. (2001) refer to a number of studies to derive a surface cooling of $0.02 \mathrm{~K}$ for $15 \mathrm{ppbv}$ of ozone loss between 1 and $3 \mathrm{~km}$, which becomes up to $0.05 \mathrm{~K}$ if the depleted air masses mix to higher altitudes.

The results presented in this paper, of widespread ozone depletion, allows these implications to be viewed in a wider context. The radiative forcing, although a relatively small amount, is likely to affect a large area over the coastal margin and sea ice zone. Further, given that chemical production of ozone during polar spring is extremely slow, this volume of depleted air is likely to ultimately be mixed to higher altitudes. The consequent dilution of free tropospheric ozone would result in a larger radiative response. The enhanced bromine chemistry is evident from satellite measurements, but the amount of ozone depletion suggested by our results supports the idea of a major shift in oxidant control over a broad region.

Finally, our results emphasise the critical role of air mass transport in driving the surface ozone signal observed at coastal sites. While some ozone depletion events, driven by local processes, are genuinely episodic, the larger-scale, regional, events are observed episodically when the wind brings ozone poor air to the observations site. The question remains whether boundary layer air over the Antarctic sea ice zone is depleted in ozone for extensive periods of time. A next step would be to probe springtime air masses directly over the sea ice zone, either with a buoy system, or with fast response ozone sensors on UAVs.

Acknowledgements. AEJ is grateful to John Turner and Gareth Marshall (BAS) for discussions around the meteorology presented in Sect. 3, and to Tony Philips for generating some publication quality figures. The autonomous network, the Halley observations, and the overall data analysis were part of the British Antarctic Survey's Polar Science for Planet Earth programme funded by the Natural Environment Research Council. The Belgrano data is obtained by collaboration agreements between Dirección Nacional del Antártico/Instituto Antártico Argentino and the Instituto Nacional de Técnica Aeroespacial of Spain. Work on the Belgrano data was partially funded by Spanish Polar Program (POL2006-00382 and CGL2004- 05419-C02-01 projects). The research in Belgium was funded by the Belgian Prodex Atmospheric Composition, Chemistry and Climate (A3C).

Edited by: J. W. Bottenheim

\section{References}

Bauguitte, S. J.-B., Brough, N., Frey, M. M., Jones, A. E., Maxfield, D. J., Roscoe, H. K., Rose, M. C., and Wolff, E. W.: A network of autonomous surface ozone monitors in Antarctica: technical description and first results, Atmos. Meas. Tech., 4, 645-658, doi:10.5194/amt-4-645-2011, 2011.

Bottenheim, J. W., Netcheva, S., Morin, S., and Nghiem, S. V.: Ozone in the boundary layer air over the Arctic Ocean: measurements during the TARA transpolar drift 2006-2008, Atmos. Chem. Phys., 9, 4545-4557, doi:10.5194/acp-9-4545-2009, 2009.

Buys, Z., Brough, N., Huey, L. G., Tanner, D. J., von Glasow, R., and Jones, A. E.: High temporal resolution $\mathrm{Br}_{2}, \mathrm{BrCl}$ and BrO observations in coastal Antarctica, Atmos. Chem. Phys., 13, 1329-1343, doi:10.5194/acp-13-1329-2013, 2013.

Choi, S., Wang, Y., Salawitch, R. J., Canty, T., Joiner, J., Zeng, T., Kurosu, T. P., Chance, K., Richter, A., Huey, L. G., Liao, J., Neuman, J. A., Nowak, J. B., Dibb, J. E., Weinheimer, A. J., Diskin, G., Ryerson, T. B., da Silva, A., Curry, J., Kinnison, D., Tilmes, S., and Levelt, P. F.: Analysis of satellite-derived Arctic tropospheric BrO columns in conjunction with aircraft measurements during ARCTAS and ARCPAC, Atmos. Chem. Phys., 12, 12551285, doi:10.5194/acp-12-1255-2012, 2012.

Frieß, U., Hollwedel, J., Konig-Langlo, G., Wagner, T., and Platt U.: Dynamics and chemistry of tropospheric bromine explosion events in the Antarctic coastal region, J. Geophys. Res., 109, D06305, doi:10.1029/2003JD004133, 2004.

Helmig, D., Oltmans, S., Carlson, D., Lamarque, J.-F., Jones, A.E., Labuschagne, C., Anlauf, K., and Hayden, K.: A review of surface ozone in the polar regions, Atmos. Environ., 41, 5138-5161, doi:10.1016/j.atmosenv.2006.09.053, 2007.

Hopper, J. F., Peters, B., Yokouchi, Y., Niki, H., Jobson, B. T., Shelson, P. B., and Muthuramu, K.: Chemical and meteorological observations at ice camp SWAN during Polar Sunrise Experiment 1992, J. Geophys. Res., 99, 25489-25498, 1994.

Hopper, J. F., Barrie, L. A., Silis, A., Hart, W., Gallant, A. J., and Dryfhout, H.: Ozone and meteorology during the 1994 Polar Sunrise Experiment, J. Geophys. Res., 103, 1481-1492, 1998.

Jacobi, H.-W., Morin, S., and Bottenheim, J. W.: Observation of widespread depletion of ozone in the springtime boundary layer of the central Arctic linked to mesoscale synoptic conditions, J. Geophys. Res., 115, D17302, doi:10.1029/2010JD013940, 2010.

Jones, A. E., Anderson, P. S., Begoin, M., Brough, N., Hutterli, M. A., Marshall, G. J., Richter, A., Roscoe, H. K., and Wolff, E. W.: BrO, blizzards, and drivers of polar tropospheric ozone depletion events, Atmos. Chem. Phys., 9, 4639-4652, doi:10.5194/acp-94639-2009, 2009.

Kaleschke, L., Richter, A., Burrows, J. P., Afe, O., Heygster, G., Notholt, J., Rankin, A. M., Roscoe, H. K., Hollwedel, J., Wagner, T., and Jacobi, H.-W.: Frost flowers on sea ice as a source of sea salt and their influence on tropospheric halogen chemistry, Geophys. Res. Lett., 31, L16114, doi:10.1029/2004GL020655, 2004.

King, J. C.: Control of near-surface winds over an Antarctic ice shelf, J. Geophys. Res., 98, 12949-12953, 1993.

Knepp, T. N., Bottenheim, J., Carlsen, M., Carlson, D., Donohoue, D., Friederich, G., Matrai, P. A., Netcheva, S., Perovich, D. K., Santini, R., Shepson, P. B., Simpson, W., Valentic, T., Williams, C., and Wyss, P. J.: Development of an autonomous sea ice 
tethered buoy for the study of ocean-atmosphere-sea ice-snow pack interactions: the O-buoy, Atmos. Meas. Tech., 3, 249-261, doi:10.5194/amt-3-249-2010, 2010.

Lacis, A. A., Weubbles, D. J., and Logan, J. A.: Radiative forcing of climate by changes in the vertical distribution of ozone, J. Geophys. Res., 95, 9971-9981, 1990.

McConnell, J. C., Henderson, G. S., Barrie, L., Bottenheim, J., Niki, H., Langford, C. H., and Templeton, E. M. J.: Photochemical bromine production implicated in Arctic boundary-layer ozone depletion, Nature, 355, 150-152, 1992.

Munro, R., Eisinger, M., Anderson, C., Callies, J., Corpaccioli, E., Lang, R., Lefebvre, A., Livschitz, Y., and Pérez Albiñana, A.: GOME-2 on Metop: From in-orbit verification to routine operations, in: The 2006 EUMETSAT Meteorological Satellite Conference, 12-16 June 2006, Helsinki, Finland, p. 48, 2006.

Rankin, A. M., Wolff, E. W., and Martin, S.: Frost flowers - implications for tropospheric chemistry and ice core interpretation, J. Geophys. Res., 107, 4683, doi:10.1029/2002JD002492, 2002.

Read, K. A., Lewis, A. C., Bauguitte, S., Rankin, A. M., Salmon, R. A., Wolff, E. W., Saiz-Lopez, A., Bloss, W. J., Heard, D. E., Lee, J. D., and Plane, J. M. C.: DMS and MSA measurements in the Antarctic Boundary Layer: impact of $\mathrm{BrO}$ on MSA production, Atmos. Chem. Phys., 8, 2985-2997, doi:10.5194/acp-82985-2008, 2008.

Richter, A., Wittrock, F., Eisinger, M., and Burrows, J. P.: GOME observations of tropospheric $\mathrm{BrO}$ in Northern Hemispheric spring and summer 1997, Geophys. Res. Lett., 25, 2683-2686, 1998.

Ridley, B. A., Atlas, E. L., Montzka, D. D., Browell, E. V., Cantrell, C. A., Blake, D. R., Blake, N. J., Cinquini, L., Coffey, M. T., Emmons, L. K., Cohen, R. C., DeYoung, R. J., Dibb, J. E., Eisele, F. L., Flocke, F. M., Fried, A., Grahek, F. E., Grant, W. B., Hair, J. W., Hannigan, J. W., Heikes, B. J., Lefer, B. L., Mauldin, R. L., Moody, J. L., Shetter, R. E., Snow, J. A., Talbot, R. W., Thornton, J. A., Walega, J. G., Weinheimer, A. J., Wert, B. P., and Wimmers, A. J.: Ozone depletion events observed in the high latitude surface layer during the TOPSE aircraft program, J. Geophys. Res., 108, 8356, doi:10.1029/2001JD001507, 2003.

Ridley, B. A., Zeng, T., Wang, Y, Atlas, E. L., Browell, E. V., Hess, P. G., Orlando, J. J., Chance, K., and Richter, A.: An ozone depletion event in the sub-arctic surface layer over Hudson Bay, Canada, J. Atmos. Chem., 57, 255-280, doi:10.1007/s10874007-9072-z, 2007.

Roscoe, H. K., Kreher, K., and Friess, U.: Ozone loss episodes in the free Antarctic troposphere, suggesting a possible climate feedback, Geophys. Res. Lett., 28, 2911-2914, 2001.

Roscoe, H. K., Brough, N., Jones, A. E., Wittrock, F., Richter, A., Van Roozendael, M., and Hendrick, F.: Resolution of an important discrepancy between remote and in-situ measurements of tropospheric BrO during Antarctic enhancements, Atmos. Meas. Tech. Discuss., 5, 5419-5448, doi:10.5194/amtd-5-5419-2012, 2012.

Salawitch, R. J., Canty, T., Kurosu, T., Chance, K., Liang, Q., da Silva, A., Pawson, S., Nielsen, J. E., Rodriguez, J. M., Bhartia, P. K., Liu, X., Huey, L. G., Liao, J., Stickel, R. E., Tanner, D. J., Dibb, J. E., Simpson, W. R., Donohoue, D., Weinheimer, A., Flocke, F., Knapp, D., Montzka, D., Neuman, J. A., Nowak, J. B., Ryerson, T. B., Oltmans, S., Blake, D. R., Atlas, E. L., Kinnison, D. E., Tilmes, S., Pan, L. L., Hendrick, F., Van Roozendael,
M., Kreher, K., Johnston, P. V., Gao, R. S., Johnson, B., Bui, T. P., Chen, G., Pierce, R. B., Crawford, J. H., and Jacob, D. J.: A new interpretation of total column $\mathrm{BrO}$ during Arctic spring, Geophys. Res. Lett., 37, L21805, doi:10.1029/2010GL043798, 2010.

Simpson, W. R., Carlson, D., Hönninger, G., Douglas, T. A., Sturm, M., Perovich, D., and Platt, U.: First-year sea-ice contact predicts bromine monoxide $(\mathrm{BrO})$ levels at Barrow, Alaska better than potential frost flower contact, Atmos. Chem. Phys., 7, 621-627, doi:10.5194/acp-7-621-2007, 2007a.

Simpson, W. R., von Glasow, R., Riedel, K., Anderson, P., Ariya, P., Bottenheim, J., Burrows, J., Carpenter, L. J., Frieß, U., Goodsite, M. E., Heard, D., Hutterli, M., Jacobi, H.-W., Kaleschke, L., Neff, B., Plane, J., Platt, U., Richter, A., Roscoe, H., Sander, R., Shepson, P., Sodeau, J., Steffen, A., Wagner, T., and Wolff, E.: Halogens and their role in polar boundary-layer ozone depletion, Atmos. Chem. Phys., 7, 4375-4418, doi:10.5194/acp-74375-2007, 2007b.

Spreen, G., Kaleschke, L., and Heygster, G.: Sea ice remote sensing using AMSR-E 89 GHz channels J. Geophys. Res.,vol. 113, C02S03, doi:10.1029/2005JC003384, 2008.

Theys, N., Van Roozendael, M., Errera, Q., Hendrick, F., Daerden, F., Chabrillat, S., Dorf, M., Pfeilsticker, K., Rozanov, A., Lotz, W., Burrows, J. P., Lambert, J.-C., Goutail, F., Roscoe, H. K., and De Mazière, M.: A global stratospheric bromine monoxide climatology based on the BASCOE chemical transport model, Atmos. Chem. Phys., 9, 831-848, doi:10.5194/acp-9-831-2009, 2009.

Theys, N., Van Roozendael, M., Hendrick, F., Yang, X., De Smedt, I., Richter, A., Begoin, M., Errera, Q., Johnston, P. V., Kreher, K., and De Mazière, M.: Global observations of tropospheric BrO columns using GOME-2 satellite data, Atmos. Chem. Phys., 11, 1791-1811, doi:10.5194/acp-11-1791-2011, 2011.

Vogt, R., Crutzen, P. J., and Sander, R.: A mechanism for halogen release from sea-salt aerosol in the remote marine boundary layer, Nature, 383, 327-330, 1996.

Wagner, T. and Platt, U.: Satellite mapping of enhanced BrO concentrations in the troposphere, Nature, 395, 486-490, doi:10.1038/26723, 1998.

Wilson, K. L. and Birks, J. W.: Mechanism and elimination of a water vapor interference in the measurements of ozone by UV absorbance, Environ. Sci. Technol., 40, 6361-6367, doi:10.1021/es052590c, 2006

Yang, X., Pyle, J. A., and Cox, R. A.: Sea salt aerosol production and bromine release: Role of snow on sea ice, Geophys. Res. Lett., 35, L16815, doi:10.1029/2008GL034536, 2008.

Yang, X., Pyle, J. A., Cox, R. A., Theys, N., and Van Roozendael, M.: Snow-sourced bromine and its implications for polar tropospheric ozone, Atmos. Chem. Phys., 10, 7763-7773, doi:10.5194/acp-10-7763-2010, 2010. 